\title{
Phosphate fertilization and inter-relationships of the agronomic and physiological characters of amaranth seeds
}

Thaís D'Avila Rosa ${ }^{1}$, Ivan Ricardo Carvalho ${ }^{2}$, Vinícius Jardel Szareski ${ }^{1}$, Francine Lautenchleger ${ }^{3}$, Ariele Paula Nadal $^{1}$, Gizele Ingrid Gadotti ${ }^{1}$, Caroline Jacome Costa ${ }^{4}$, Francisco Amaral Villela ${ }^{1}$

${ }^{1}$ Universidade Federal de Pelotas - UFPEL. ${ }^{2}$ Universidade Regional do Noroeste do Estado do Rio Grande do Sul UNIJUI. ${ }^{3}$ Universidade Estadual do Centro Oeste - UNICENTRO. ${ }^{4}$ Empresa Brasileira de Pesquisa Agropecuária EMBRAPA. E-mail: carvalho.ircii@gmail.com

\begin{abstract}
The objective of this work was to evaluate the effect of different doses of phosphorus in the growth and development of amaranth plants and in the physiological quality of the seeds produced, as well as to identify the interrelationships between the morphological and physiological attributes. The experiment was carried out in the agricultural crop 2016/2017 in Federal University of Pelotas. The experimental design was a randomized block in which the treatments were arranged in five replications. The analysis of variance revealed a significance of $5 \%$ probability through the characters, plant height, dry mass of the plant shoot, seed yield, germination and accelerated aging these results demonstrate that these attributes are influenced by the $\mathrm{P}_{2} \mathrm{O}_{5}$ doses, in contrast, the chlorophyll index. The Amaranthus cruentus species expresses variability to the morphological attributes, yield components and seed quality produced in relation to the use of phosphate fertilization. Doses comprising 100 to $200 \mathrm{~kg} \mathrm{ha}^{-1}$ of $\mathrm{P}_{2} \mathrm{O}_{5}$ tend to potentiate plant height, dry biomass accumulation, yield, germination and vigor of the seeds produced. Plants with greater stature and accumulation of biomass increase the proportion of photosynthetic pigments, being these determinants for the production and quality of seeds produced of amaranth in the extreme south of Brazil.
\end{abstract}

Keywords: Amaranthus cruentus; phosphorus; germination, vigor.

\section{Adubação fosfatada e inter-relações para os caracteres agronômicos e fisiológicos de sementes de amaranto}

\section{Resumo}

O objetivo deste trabalho foi avaliar o efeito de diferentes doses de fósforo no crescimento e desenvolvimento de plântulas de amaranto e na qualidade fisiológica das sementes produzidas, bem como, identificar as inter-relações entre os atributos morfológicos e fisiológicos. O experimento foi realizado na safra agrícola 2016/2017 da Universidade Federal de Pelotas. O delineamento experimental foi o de blocos casualizados, em que os tratamentos foram dispostos em cinco repetições. A análise de variância revelou significância a $5 \%$ de probabilidade para os caracteres, altura da planta, massa seca da parte aérea, rendimento de sementes, germinação e envelhecimento acelerado. Os resultados demonstram que esses atributos são influenciados pelas doses de $\mathrm{P}_{2} \mathrm{O}_{5}$, resposta contraditória para o índice de clorofila. A espécie Amaranthus cruentus expressa variabilidade quanto aos atributos morfológicos, componentes de produção e qualidade das sementes produzidas em relação ao uso da adubação fosfatada. Doses compreendendo 100 a $200 \mathrm{~kg} \mathrm{ha}_{-1}$ de $\mathrm{P}_{2} \mathrm{O}_{5}$ tendem a potencializar a altura das plantas, o acúmulo de biomassa seca, o rendimento, a germinação e o vigor das sementes produzidas. Plantas com maior estatura e acúmulo de biomassa aumentam a proporção de pigmentos fotossintéticos, sendo esses determinantes para a produção e qualidade de sementes produzidas de amaranto no extremo sul do Brasil.

Palavras-chave: Amaranthus cruentus; fósforo; germinação, vigor. 


\section{Introduction}

Amaranth is a species belonging to the Amaranthaceae family, was domesticated in America more than 6000 years ago by civilizations, and later dispersed to other regions. In addition to the use of their seeds in human and animal nutritional complementation, amaranth leaves can also be consumed in natura, a fact that has been evidenced since Prehistory before and during the domestication process (RASTOGI; SHUKLA, 2013).

This crop can be used as a forage species, as well as, used in soil protection (FERREIRA et al., 2014) due to its large leaf area. Some genotypes of Amaranthus cruentus show high stability related to their productivity and adaptation to various conditions of the growing environment (GARCIA-PEREYRA et al., 2011), which makes the crop quite promising in this regard. Research by Erasmo et al. (2004), showed that the amaranth showed a good growth when submitted to adverse conditions of air temperature and water deficit, as well as, some varieties express tolerance to high concentrations of salts and aluminum toxicity in acid soils.

Amaranth is commonly used in soybean or maize succession, it is an excellent source of proteins, fibers, minerals and vitamins, being used both in natura or in industrialized forms, this justifies its increasing exploitation in Brazil (BRAMBRILLA et al., 2008). In Brazil, amaranth already has a cultivar registered by Embrapa being available for commercialization, called BRS Alegria. The crop can express yields higher than two tons of seeds per hectare, however, high yields depend on some factors such as management and adequate fertilization. In countries such as the United States of America, where cultivation of amaranth occurs commercially, fertilization is performed according to the nutritional requirements of the plant being based on soil analysis, ie the amount of fertilizer applied must be defined according to the results and bulletins of each agricultural region where the crop will be planted, in Brazil there are no specific recommendations for amaranth cultivation (TEIXEIRA et al., 2003).

In this context, phosphorus is an essential macronutrient for plants, where its low availability may compromise leaf expansion, result in low accumulation of dry matter, growth, development and yield of seeds. In addition, this nutrient is important for the definition of the productivity of the crops, being integral of cell membranes, nucleic acids, constituent of the readily available energy compounds called ATP (adenosine triphosphate), being these vital to the process of germination, emergence of the seedlings and photosynthesis of plants (GUERRA et al., 2006; SZARESKI et al., 2018). In this context, seeds are characterized as the form of consumption of amaranth, and the greater input of phosphate fertilizer can indirectly increase the accumulation of phosphorus (P), magnesium $(\mathrm{Mg})$ and zinc $(\mathrm{Zn})$ contained in the seeds and increase the nutritional value of this crop (SALUM et al., 2008; CARVALHO et al., 2017).

Nitrogen, potassium and phosphorus requirements are $25 \mathrm{~kg} \mathrm{ha}^{-1}, 80 \mathrm{~kg} \mathrm{ha}^{-1}$ and $80 \mathrm{~kg}$ $\mathrm{ha}^{-1}$, respectively. In the literature, the fertilization recommendations for the Southern Region of Brazil, specifically for Rio Grande do Sul, are scarce for the amaranth crop, therefore, since there is no recommendation for fertilization, the technical indications for the Brazilian Cerrado Region (TEIXEIRA et al., 2003). Due to the great interest in this crop, being for alternative of cultivation, or for use in the off season, added to the growth of amaranth production, studies on this subject are of fundamental importance, in this way, the objective of this work was to evaluate the effect of different doses of phosphorus in the growth and development of plants and in the physiological quality of the seeds produced, as well as to identify the interrelationships between the morphological and physiological attributes.

\section{Material and Methods}

The experiment was carried out in the agricultural crop 2016/2017 at the Campus of the Federal University of Pelotas, Capão do Leão - RS at coordinates 310 52 '00 "S and 520 21' 24" W, altitude of 13 meters. The experiment was conducted in a "Pampean Arc" greenhouse, arranged in a North-South direction, coated with a low density polyethylene film (150 $\mu \mathrm{m}$ thick), comprising an area of $210 \mathrm{~m}^{2}$ ( $10 \times 21$ meters).

Eight liters containers filled with soil classified as solodic eutrophic Planosol were used, belonging to the Pelotas mapping unit (EMBRAPA, 2012). Before sowing, soil samples were collected, which showed the following characteristics: $\mathrm{pH}$ (water): $5.43 ; \mathrm{H}+\mathrm{Al}: 5.1 \mathrm{cmol}^{\mathrm{c}}$ $\mathrm{dm}^{-3}$; organic matter: $3.4 \mathrm{~g} \mathrm{dm}^{-3} ; \mathrm{P}: 28.66 \mathrm{mg} \mathrm{dm}$ ${ }^{3}$; K: $10.4 \mathrm{cmolc} \mathrm{dm}^{-3}$; Ca: $3.0 \mathrm{cmol} \mathrm{dm}^{-3}$; $\mathrm{Mg}: 1.5$ 
cmol / $\mathrm{dm}^{-3}$; micronutrients $\left(\mathrm{mg} \mathrm{dm}^{-3}\right)$ : Cu 1,5; $\mathrm{Zn}$ : 5.1. The $\mathrm{B}, \mathrm{Fe}, \mathrm{Mn}$ and $\mathrm{Al}^{3+}$ content was zero.

In this study, the BRS Alegria amaranth seeds with $90 \%$ germination were used. The germination was measured using the standard germination test established by the Rules for Seed Analysis (BRASIL, 2009). The sowing was done in the first half of October, using 10 seeds per container, fifteen days after emergence, the thinning was done leaving four plants per container, and the treatments were arranged in five replications. The treatments corresponded to five doses of phosphorus in the base, in the form of triple superphosphate, being $0,50,100,200$ and $400 \mathrm{~kg}$ ha-1 of P2O5. The standard dose of $100 \mathrm{~kg}$ ha- 1 of nitrogen in the form of ammonium sulfate ( $21 \%$ nitrogen and $23 \%$ sulfur) was used in the treatments. After incorporation of the fertilizers, irrigations were carried out up to the field capacity twice a day for 30 days after the emergence of the seedlings. Pest control and disease control were unnecessary throughout the study period. At 120 days after emergence of the seedlings the following characters were measured:

Plant height (PH): measured using a graduated ruler through the distance between the soil level to the end of the panicle, results expressed in centimeters $(\mathrm{cm})$.

Dry matter of the plant shoot (DM): the shoot of the plants was collected five centimeters above the soil base, these were placed in kraft paper containers and subjected to a forced ventilation oven at 60 ㅇ $\mathrm{C}$ until obtaining the constant mass, after the dry mass was measured on a digital scale, results expressed in grams (g).

Chlorophyll index $(\mathrm{Cl})$ : measured by a chlorophyllometer (model SPAD-502), with three readings at different positions of the basal leaf, being the third leaf from the base to the apex of the plant, intermediate and randomly selected in the average part of the plant and apical in the second leaf below the panicle), procedure performed in three plants of each experimental unit, results expressed in index.

Seed yield (SY): at 120 days after emergence, the seeds were harvested and dried at $25^{\circ} \mathrm{C}$ in an oven with heated air, then the seed mass of each panicle was measured, results expressed in grams (g) per plant.

The attributes of the physiological quality of amaranth seeds were determined according to the following procedures:
Moisture content: determined in two replicates of five grams of seed using the oven method at $105^{\circ} \mathrm{C} \pm 3^{\circ} \mathrm{C}$ for 24 hours, being obtained by the difference between the wet and dry mass of the seeds, according to the Rules for Seed Analysis (BRASIL, 2009).

Germination (G): four subsamples of 50 seeds per treatment were used. These were distributed over two sheets of blotting paper, moistened with distilled water equivalent to 2.5 times the mass of the dried substrate and placed to germinate at the constant temperature of $25^{\circ} \mathrm{C}$ in a BOD (Biochemical Oxigen Demand) type chamber. The evaluation was performed at 14 days after sowing. The results were expressed as percentage of normal seedlings (\%) (BRASIL, 2009).

Accelerated aging (AA): conducted in transparent plastic boxes of dimensions of $11.5 \mathrm{x}$ $11.5 \times 3.5 \mathrm{~cm}$, and individual compartments (small chambers), where in its interior metal screen supports covered with void fabric were fixed, due to the size of the seeds used, this made it possible to avoid them having contact with the solution. On the surface of each metal screen approximately 1.5 grams of seeds were distributed with a uniform layer. These packages contained $40 \mathrm{~mL}$ of dilute $\mathrm{NaCl}$ solution $(11 \mathrm{~g}$ of $\mathrm{NaCl}$ per $100 \mathrm{~mL}$ of water, aging with unsaturated $\mathrm{NaCl}$ - SSNS solution) and subjected to an air temperature of $41^{\circ} \mathrm{C}$ for 72 hours, after which the seeds were directed to the germination test as described previously, the normal seedling count occurred on the fifth day after sowing (OHLSON et al., 2010), results in percentage of normal seedlings (\%).

The experimental design was a randomized block in which the treatments were arranged in five replications. The data obtained were submitted to a $5 \%$ probability analysis, where the assumptions of the statistical model were verified, the characters that showed significance were submitted to linear regression, where the highest significant degree of the polynomial was tested at $5 \%$ probability by t-test. Afterwards, all the characters studied were linearly correlated in order to understand the association tendencies, as well as the morphological groups (plant height - $\mathrm{PH}$, dry mass - DM, chlorophyll index - $\mathrm{Cl}$, seed yield - SY) that corresponded to group II, as well as, group I was represented by the physiological characters (germination - $\mathrm{G}$ and accelerated aging - AA), these were subjected to canonical correlations 
with the purpose of defining multivariate interrelations between these characters, the significance of these associations was obtained by the ratio between the restricted maximum likelihood (LRT).

\section{Results and Discussion}

The analysis of variance revealed a significance of $5 \%$ probability through the characters, plant height $(\mathrm{PH})$, dry mass of the plant shoot (DM), seed yield (SY), germination (G) and accelerated aging (AA), these results demonstrate that these attributes are influenced by the $\mathrm{P}_{2} \mathrm{O}_{5}$ doses, in contrast, the chlorophyll index $(\mathrm{Cl})$, did not reveal variability in relation to the quantitative levels used (Table 1 ).

Table 1. Analysis of variance for germination (G), Accelerated aging (AA), plant height (PH), dry mass (DM), seed yield (SY) and chlorophyll index $(\mathrm{Cl})$ for the amaranth BRS Alegria cultivar, produced in different doses of $\mathrm{P}_{2} \mathrm{O}_{5}$ in the state of Rio Grande do Sul.

\begin{tabular}{lccccccc}
\hline \multirow{2}{*}{ VF } & \multicolumn{7}{c}{ MS } \\
\cline { 2 - 8 } & DF & G & AA & PH & DM & SY & $\mathrm{Cl}$ \\
\hline Doses of $\mathrm{P}_{2} \mathrm{O}_{5}$ & 4 & $2003.26^{*}$ & $1165.70^{*}$ & $0.81^{*}$ & $1.18^{*}$ & $79.59^{*}$ & $219.43^{\text {ns }}$ \\
Repetitions & 4 & 3.56 & 1.00 & 0.00 & 0.05 & 0.05 & 2.53 \\
Error & 16 & 17.73 & 13.07 & 0.01 & 0.03 & 0.32 & 1.84 \\
\hline \multicolumn{1}{c}{$\mathrm{CV}(\%)$} & & 7.83 & 7.99 & 11.81 & 11.03 & 12.30 & 2.90 \\
\hline
\end{tabular}

* Germination (G), Accelerated Aging (AA), plant height (PH), dry mass (DM), seed yield (SY) and chlorophyll index (CI) of amaranth cultivar BRS Alegria produced at different doses of $\mathrm{P}_{2} \mathrm{O}_{5}$ in the state of Rio Grande do Sul.

The character plant height $(\mathrm{PH})$ showed variability along the increment of the phosphorus doses used, adjusting to a statistical regression model with $94 \%$ reliability $\left(R^{2}: 0.94\right)$. It was verified that the dose of $200 \mathrm{~kg} \mathrm{ha}^{-1}$ of phosphorus obtained the greatest magnitude for the plant height. It was defined that for this character the optimal plateau is between $100 \mathrm{~kg}$ $\mathrm{ha}^{-1}$ and $200 \mathrm{~kg} \mathrm{ha}$ of phosphorus, where it results in plants with an average height of 1.10 meters. Doses of phosphorus up to $400 \mathrm{~kg} \mathrm{ha}^{-1}$ result in marked decreases for this character, showing plants with stature $50 \%$ lower than those obtained through the greater magnitude.

Phosphorus plays an essential role in cell energy transfer, as well as photosynthesis and respiration of plants, as well as being a structural element of nucleic acids, coenzymes, phospholipids and phosphoproteins. Thus, phosphorus deficiency at the beginning of the vegetative cycle of any crop may hinder the development of the plant, and the subsequent supply of such an element, even at adequate levels, will not be sufficient for its recovery (GRANT et al., 2001). At the dose of $0 \mathrm{mg} \mathrm{dm}^{-3}$ of phosphorus a plant height of approximately 0.3 meters was observed (Figure 1). Domingos et al. (2005), when analyzing the height of amaranth plants as a function of the fertilization of NPK in the formulation of $05-25-15$, observed that the greatest magnitude was verified when the dose of the concentrated formulation was used in the order of $400 \mathrm{~kg} \mathrm{ha}^{-1}$ of phosphorus. 
Figure 1. Height of amaranth plants, cultivar BRS Alegria as a function of the different doses of phosphorus $\left(0,100,200,300\right.$ and $400 \mathrm{~kg} \mathrm{ha}^{-1}$ of $\left.\mathrm{P}_{2} \mathrm{O}_{5}\right)$ grown in the state of Rio Grande do Sul.

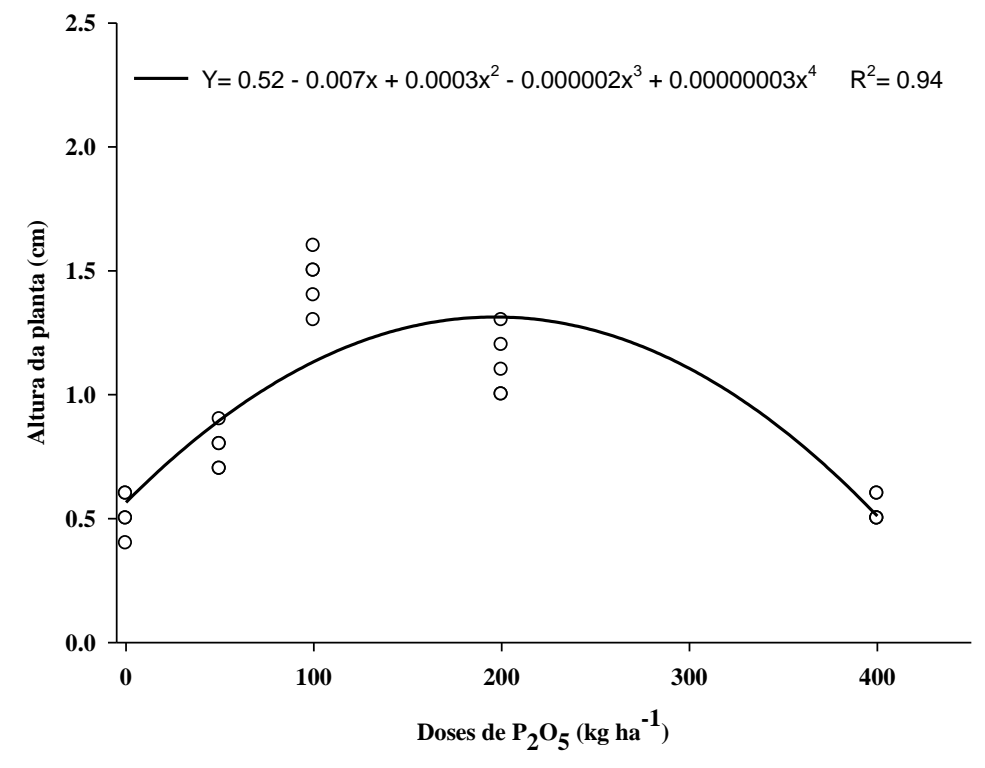

The character dry mass of the plant shoot (DM) showed an estimated dry matter yield at the level of fertilization of $100 \mathrm{~kg} \mathrm{ha}{ }^{-1}$ of phosphorus of 2.5 grams per plant. The increase of the biomass of the amaranth plants was verified until the phosphorus dose of $100 \mathrm{~kg} \mathrm{ha}^{-1}$, with the increase of the doses for 200 and $400 \mathrm{~kg}$ $\mathrm{ha}^{-1}$, there was a reduction of the dry mass of the plants being of approximately 1.8 e 1.3 grams per plant, respectively. The biomass mass difference between the largest $\left(100 \mathrm{~kg} \mathrm{ha}^{-1}\right)$ and the smallest magnitude $\left(400 \mathrm{~kg} \mathrm{ha}^{-1}\right)$ was $1.2 \mathrm{~g} /$ plant (Figure 2).

Figure 2 - Mass of dry matter of amaranth plants, BRS Alegria cultivar in the state of Rio Grande do Sul, according to the different doses of phosphorus $\left(0,100,200,300\right.$ and $400 \mathrm{~kg} \mathrm{ha}^{-1}$ of $\left.\mathrm{P}_{2} \mathrm{O}_{5}\right)$.

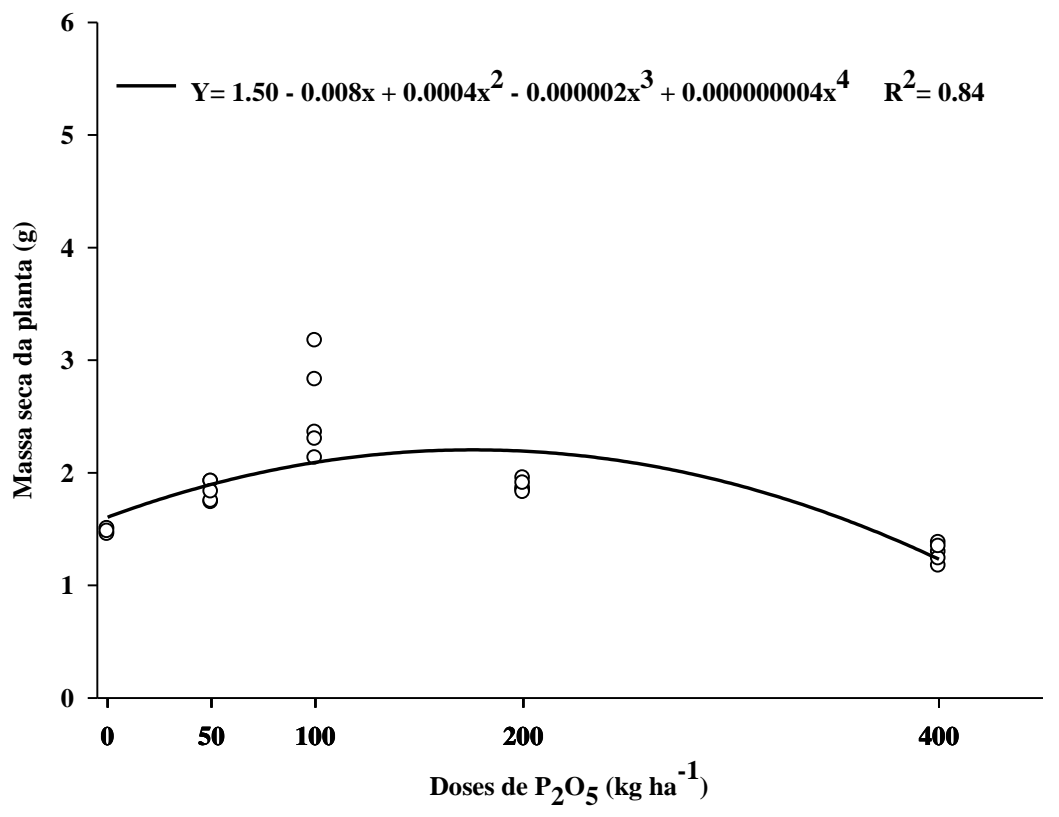


In the literature, there are few references that deal with excess phosphorus in plants, although some authors argue that large amounts of phosphorus applied can cause damage to plants and must be compatible with crop demand (ROGÉRIO et al., 2012). In plants of andiroba (CarapaguianensisAubl.) at high doses of phosphorus 300 and $450 \mathrm{mg} \mathrm{dm}^{-3}$, the plants exhibited visual symptoms of leaf injuries characterized by reddish-yellow streaks along the veins (NEVES et al., 2004; SAMPAIO, 1997).

Seed yield (SY) showed a quadratic response due to the increase up to $100 \mathrm{~kg} \mathrm{ha}^{-1}$ of phosphorus (Figure 3). Teixeira et al. (2003) identified that for BRS Alegria amaranth cultivar grown in the Brazilian Cerrado, it is recommended the maintenance fertilization with $60 \mathrm{~kg} \mathrm{ha}^{-1}$ of $\mathrm{P}_{2} \mathrm{O}_{5}$ when producing more than two tons per hectare. In an experiment carried out in Bolivia with amaranth, using mineral fertilization through the formulation of NPK (80-80-40), grain yield of $2.3 \mathrm{t} \mathrm{ha}^{-1}$ was verified (APAZA-GUTIERREZ et al., 2002).

Figure 3 - Seed yield of amaranth plants, BRS Alegria cultivar in the State of Rio Grande do Sul, according to the different doses of phosphorus $\left(0,100,200,300\right.$ and $400 \mathrm{~kg} \mathrm{ha}^{-1}$ of $\left.\mathrm{P}_{2} \mathrm{O}_{5}\right)$.

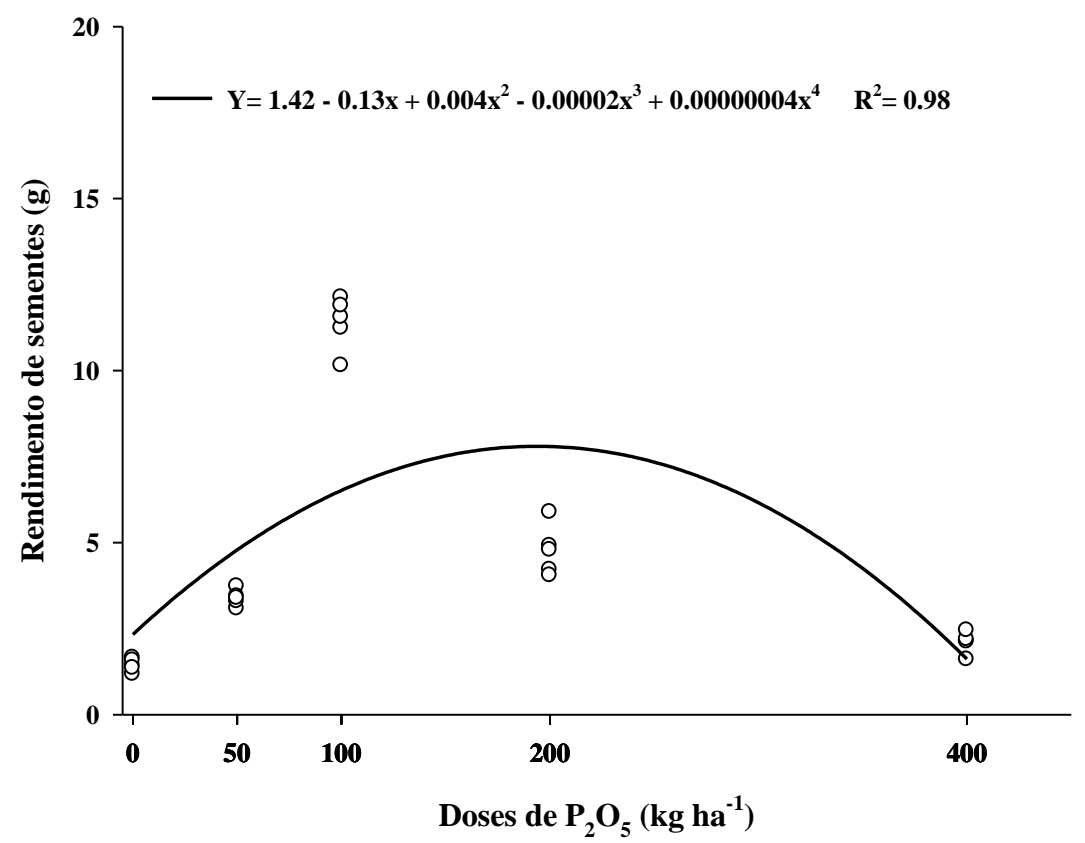


Figure 4-Percentage of germination of amaranth seeds of the cultivar BRS Alegria as a function of different levels of phosphorus $\left(0,100,200,300\right.$ and $400 \mathrm{~kg} \mathrm{ha}^{-1}$ of $\left.\mathrm{P}_{2} \mathrm{O}_{5}\right)$ produced in the state of Rio Grande do Sul.

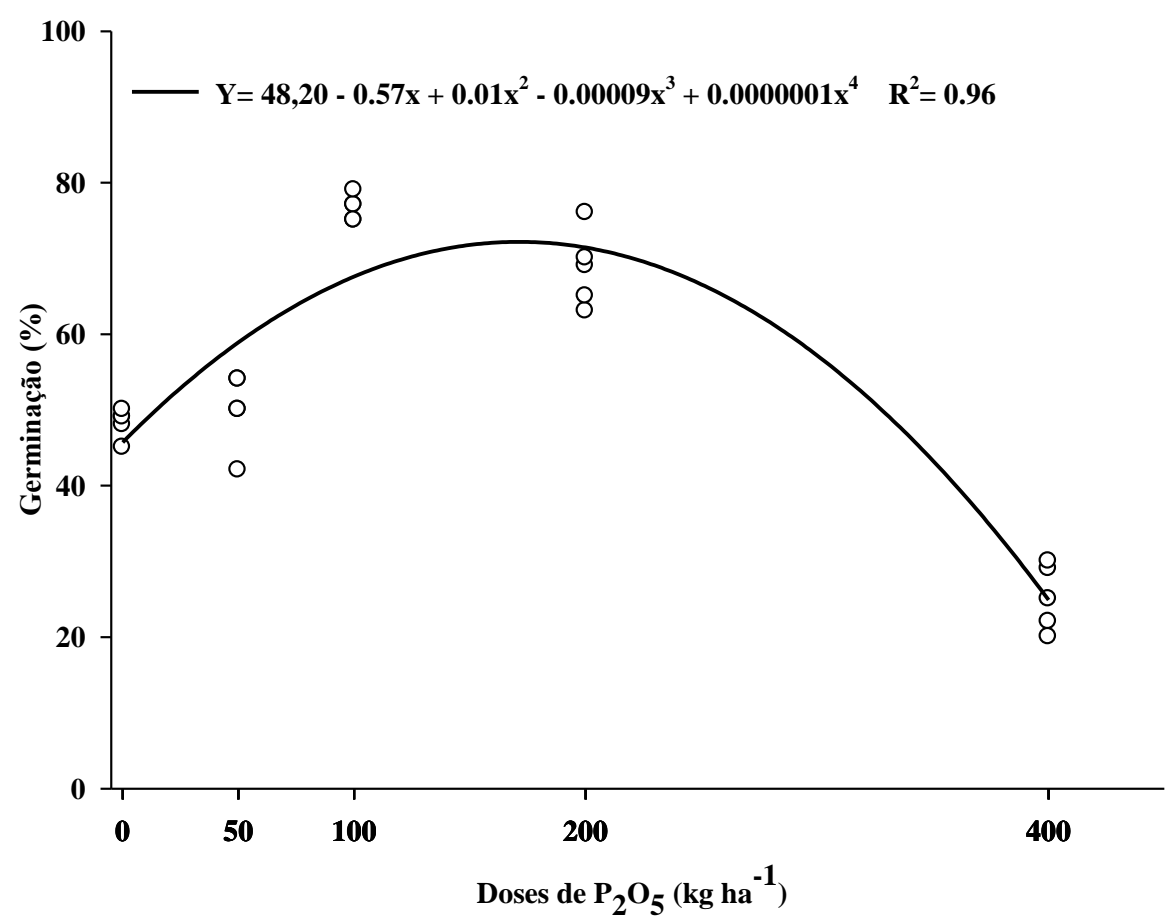

Figure 5. Accelerated aging of amaranth seeds of BRS Alegria cultivar in the state of Rio Grande do Sul, according to the different doses of phosphorus $\left(0,100,200,300\right.$ and $400 \mathrm{~kg} \mathrm{ha}^{-1}$ of $\left.\mathrm{P}_{2} \mathrm{O}_{5}\right)$, produced in the state of Rio Grande do Sul.

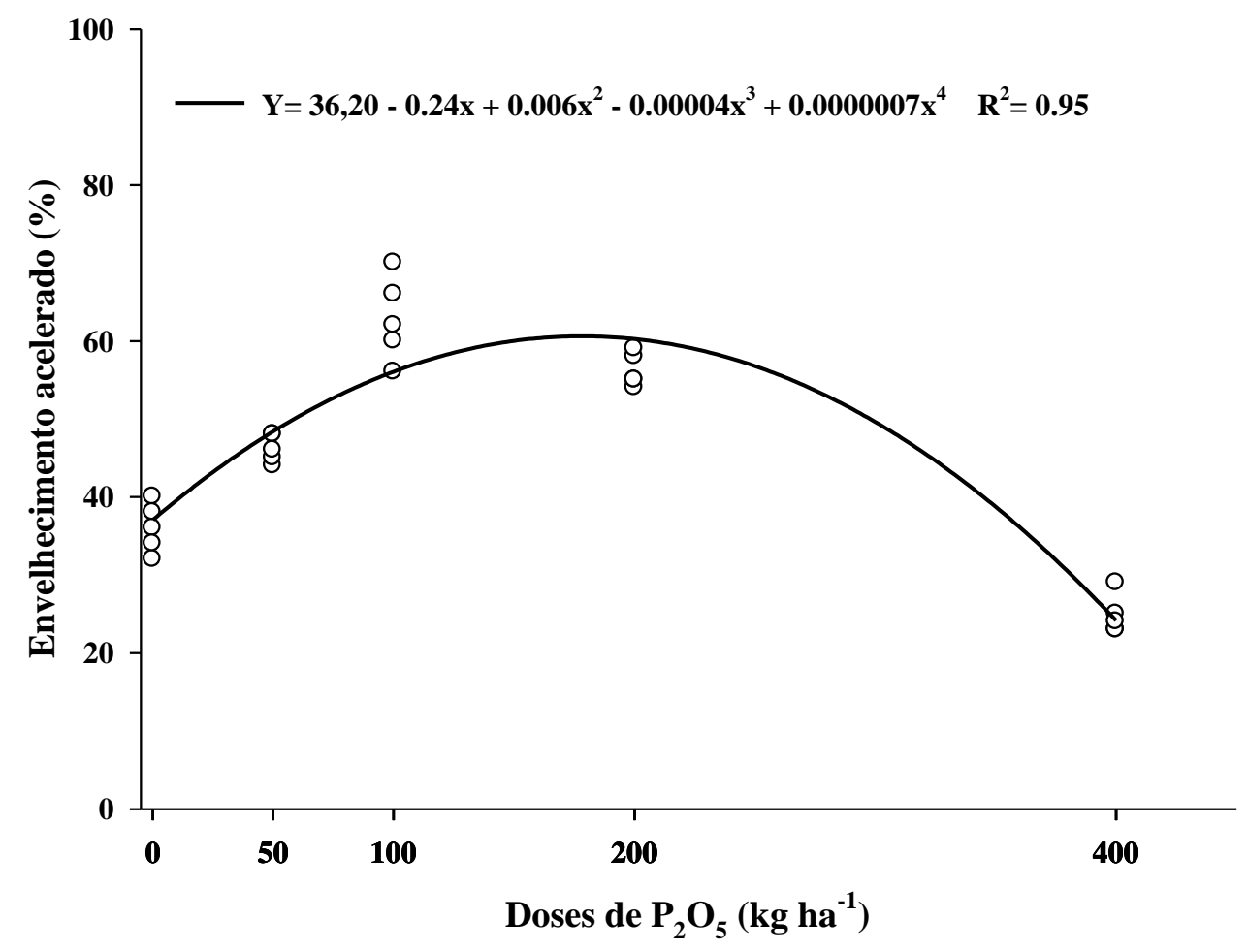

In the absence of phosphorus application $\left(0 \mathrm{~kg} \mathrm{ha}^{-1}\right)$ the vigor of the seeds measured by the accelerated aging test was approximately 35\%, using the dose of $50 \mathrm{~kg} \mathrm{ha}^{-1}$ of phosphorus, there was an increase of this attribute to $46 \%$, justifying that phosphate fertilization may result 
in an improvement of the physiological potential of amaranth seeds. Research with Crotalaria juncea defined that phosphorus was essential to increase the germination and seed vigor of this species (DOURADO et al., 2001).

The linear correlation analysis (Table 2) was carried out in order to identify the trend of association between the five characters of interest, and it was possible to verify significance for all associations at $5 \%$ probability by the $t$ test.
Where plants with high stature tend to increase the accumulation of dry mass in their tissues, this results in positive effects to the seed yield per plant and chlorophyll index of photosynthetic tissues. These morphological attributes of seed yield when in synergism result in an increase in the physiological potential of seeds of this species.

Table 2. Linear and canonical correlation applied to morphological and physiological characters of BRS Alegria cultivar, cultivated as a function of different doses of $\mathrm{P}_{2} \mathrm{O}_{5}$ in the state of Rio Grande do Sul.

\begin{tabular}{|c|c|c|c|c|c|}
\hline & $\mathrm{AA}$ & $\mathrm{PH}$ & DM & SY & $\mathrm{Cl}$ \\
\hline G & $0.94 *$ & $0.84^{*}$ & $0.81 *$ & $0.76^{*}$ & $0.73^{*}$ \\
\hline $\mathrm{AA}$ & & $0.89 *$ & $0.81^{*}$ & $0.80^{*}$ & $0.77^{*}$ \\
\hline $\mathrm{PH}$ & & & $0.86^{*}$ & $0.91^{*}$ & $0.79 *$ \\
\hline DM & & & & $0.86^{*}$ & $0.87^{*}$ \\
\hline SY & & & & & $0.90^{*}$ \\
\hline \multicolumn{6}{|c|}{ Group I (Physiological characteristics of seeds) } \\
\hline & & \multicolumn{4}{|c|}{0.86} \\
\hline & & \multicolumn{4}{|c|}{0.92} \\
\hline \multicolumn{6}{|c|}{ Group II (Morphological characters of plants) } \\
\hline & & \multicolumn{4}{|c|}{0.89} \\
\hline & & \multicolumn{4}{|c|}{0.80} \\
\hline & & \multicolumn{4}{|c|}{0.80} \\
\hline & & \multicolumn{4}{|c|}{0.77} \\
\hline & & \multicolumn{4}{|c|}{0.92} \\
\hline & & \multicolumn{4}{|c|}{$0.13^{*}$} \\
\hline
\end{tabular}

Germination (G), Accelerated aging (AA), plant height (PH), dry mass (DM), seed yield (SY) and chlorophyll index (Cl) of the amaranth cultivar BRS Alegria produced in different doses of $\mathrm{P}_{2} \mathrm{O}_{5}$ in the state of Rio Grande do Sul.

The analysis of the canonical correlations has as premise to identify the associations between distinct groups of measured variables, and to define a profile of multivariate interrelationships determinant for the predetermined groups. These effects were attributed to the BRS Alegria amaranth cultivar where the characteristics of Group I correspond to the physiological ones, being germination (G) and accelerated aging (AA), as well as, Group II corresponded to the morphological characters and components of the yield, being plant height $(\mathrm{PH})$, dry matter (DM), seed yield (SY) and chlorophyll index $(\mathrm{Cl})$, in this way, a significance was identified for a canonical pair at 5\% probability by the maximum likelihood ratio, in the same way, a high inter-group correlation ( $r=$ 0.92) was obtained, justifying the inter-class dependence of the attributes measured (Table 2).
Therefore, the increase in the physiological potential of both germination $(G)$ and seed vigor obtained by the accelerated aging test (AA) was determined by the identification of plants with greater stature and accumulation of tissues in their aerial part, these tend to show high chlorophyll indexes that benefit the photosynthetic activity, as well as, they result in plants with higher seed productivity. These interrelationships define that phosphate fertilization, besides increasing the morphological attributes of amaranth plants, quantitatively and qualitatively benefit seed production.

\section{Conclusion}

The Amaranthuscruentus species expresses variability to the morphological attributes, yield components and seed quality 
produced in relation to the use of phosphate fertilization.

Doses comprising 100 to $200 \mathrm{~kg} \mathrm{ha}^{-1}$ of $\mathrm{P}_{2} \mathrm{O}_{5}$ tend to potentiate plant height, dry biomass accumulation, yield, germination and vigor of the seeds produced.

Plants with greater stature and accumulation of biomass increase the proportion of photosynthetic pigments, being these determinants for the production and quality of seeds produced of amaranth in the extreme south of Brazil.

\section{References}

APAZA-GUTIERREZ, V.; ROMERO-SARAVIA, A.; GUILLÉN-PORTAL, F. R.; BALTERSPERGER, D. D. Response of grain amaranth production to density and fertilization in Tarija, Bolivia. In: JANICK, J.; WHIPKEY, A. (Eds.). Trends in new crops and new uses. Alexandria: ASHS, 2002. p. 107-109.

BRASIL. Ministério da Agricultura, Pecuária e Abastecimento. Regras para análise de sementes. Brasília: Mapa/ACS, 2009. 399p.

CARVALHO, I. R.; NARDINO, M.; FOLLMANN, D. N.; DEMARI, GH.; OLIVOTO, T.; PELEGRIN, A. J.; SZARESKI, V. J.; FERRARI, M.; ROSA, T.C.; KOCH, F.; AISENBERG, G. R.; PEDO, T.; AUMONDE, T. Z.; SOUZA, V.Q. Path analysis of grain yield associated characters in wheat (Triticumaestivum L.) Brasilians. AUST J CROP SCI, v.11, p.14061410, 2017. DOI: 10.21475 / ajcs.17.11.11.pne484

DOMINGOS, V. D.; ERASMO, E. A. L.; SILVA, J. I. C.; CAVALCANTE, G.D.; SPEHAR, C. R. Crescimento, produção de grãos e biomassa de cultivares de amaranto (Amaranthuscruentus) em função de adubação com NPK. Bioscience Journal, v.21, n.3, p.29- 39, 2005.

DOURADO, M.C.; SILVA, T.R.B.; BOLONHEZI, A.C. Matéria seca e produção de grãos de Crotalariajuncea L. submetida à poda e adubação fosfatada. ScientiaAgricola, v.58, n.2, p.287-293, $2001 . \quad$ https://doi.org/10.1590/S0103$\underline{90162001000200011}$

EMBRAPA. Sistema Brasileiro de Classificação de Solo. 2. ed. Rio de Janeiro: EMBRAPA, 2012. 306 p.
ERASMO, E. A. L.; DOMINGOS, V. D.; SPEHAR, C. R.; DIDONET, J.; SARMENTO, R. A.; CUNHA, A. M. Avaliação de cultivares de amaranto (Amaranthus spp.) em sistema plantio direto no sul de Tocantins. Bioscience Journal, Uberlândia, v.20, n.1, p.171-176, 2004.

FERREIRA, C.C.; RIBEIRO JÚNIOR, W.Q.; RAMOS, M.L.G.; SPEHAR, C.R.; FARIAS, T.R.R. Efeito da densidade de semeadura e doses de nitrogênio sobre a produtividade e biometria de amaranto, no Cerrado do Planalto Central. Bioscience Journal, v.30, p.534-546, 2014.

GARCIA-PEREYRA, J.; VALDÉS-LOZANO, C. G. S.; ALEJANDRE-ITURBIDSE, G.; FIERRO, I. V.; GÓMEZ, O. G. A. Interaction genótipo $x$ ambiente $y$ análisis de estabilidad em genótipos de amaranto (Amaranthus spp.). Oyton, v.60, p.167-173, 2011.

GRANT, C.A.; PLATEN, D.N.; TOMAZIEWICZ, D.J.; SHEPPARD, S.C. A importância do fósforo no desenvolvimento inicial da planta. Informações Agronômicas, Piracicaba, n.95, 2001.

GUERRA, C.A.; MARCHETTI, M.E.; ROBAINA, A.D.; SOUZA, C.F.; GONÇALVES, M.C.; NOVELINO, J.O. Qualidade fisiológica de sementes de soja em função da adubação com fósforo, molibdênio e cobalto. Acta ScientiarumAgronomy, v.28, n.1, p.91-97, 2006. https://doi.org/10.4025/actasciagron.v28i1.1678

MARSCHNER, $H$. Mineral nutrition of higher plants. 2. ed. London: Academic Press, 1995. 889 p.

NEVES, O. S. C.; BENEDITO, D. S.; MACHADO, R. V.; CARVALHO, J. G. Crescimento, produção de matéria seca e acúmulo de $\mathrm{N}, \mathrm{P}, \mathrm{K}, \mathrm{Ca}, \mathrm{Mg}$ e $\mathrm{S}$ na parte aérea e mudas de andiroba (CarapaguianensisAubl.) cultivadas em solo de várzea, em função de diferentes doses de fósforo. Revista Árvore, v.28, p.343-349, 2004. https://doi.org/10.1590/S0100$\underline{67622004000300004}$ 
OHLSON, O.C.; KRZYZANOWSKI, F.C.; CAIEIRO, J.T.; PANOBIANCO, M. Teste de envelhecimento acelerado em sementes de trigo. Revista Brasileira de Sementes, v.32, n.4, 118-124, 2010. https://doi.org/10.1590/S0101$\underline{31222010000400013}$

RASTOGI, A.; SHUKLA, S. Amaranth: a new millennium crop of nutraceutical values. Critical Reviews in Food Science and Nutrition, v.53, n.3, p.109-25, 2013. https://doi.org/10.1080/10408398.2010.517876

ROGÉRIO, F.; SANTOS, J.I.; SILVA, T.R.B.; MIGLIAVACCA, R.A.; GOUVEIA, B.; BARBOSA, M.C. Efeito de doses de fósforo no desenvolvimento da cultura do crambe. Bioscience Journal, v.28, n.1, p. 251-255, 2012.

SALUM, J.D. et al. Características químicas e fisiológicas de sementes de feijão em função do teor de fósforo na semente e doses de fósforo no solo. Revista Brasileira de Sementes, v.30, n.1, p.140-149, 2008. https://doi.org/10.1590/S0101$\underline{31222008000100018}$

SAMPAIO, L. S. Resposta de plantas jovens de açaí à adubação fosfatada e à inundação em solos de várzea. 1997. 150f. Dissertação (Mestrado) - Universidade Federal de Lavras, Lavras, 1997.

SZARESKI, V. J.; CARVALHO, I. R.; KEHL, K.; LEVIEN, A. M.; NARDINO, M.; DELLAGOSTIN, S. M.; DEMARI, GH.; LAUTENCHLEGER, F.; VILLELA, F. A.; PEDO, T.; SOUZA, V. Q.; AUMONDE, T. Z. Evaluation of the adaptability and stability of wheat genotypes using a phenotypic index of seed vigor. Pesquisa Agropecuária Brasileira, v.53, p.727-735, 2018. https://doi.org/10.1590/s0100-

$\underline{204 \times 2018000600009}$

TEIXEIRA, D. L.; SPEHAR, C. R.; SOUZA, L. A. C. Caracterização agronômica de amaranto para cultivo na entressafra no Cerrado. Pesquisa Agropecuária Brasileira, v.38, n.1, p.45-51, 2003. https://doi.org/10.1590/S0100$\underline{204 \times 2003000100006}$ 